\title{
Designer infant formulas: making a killing
}

\author{
Hasantha Gunasekera
}

$J$ R Soc Med 2005;98:551-552

December is an advertiser's dream but who stops to reflect on how marketing affects our health? Consider the impact of the pictures of adorable, thriving babies looking down at us beckoningly from the supermarket infant formula section. There are choices for every maternal anxiety: formulas for newborns; young infants; older infants; the lactose-intolerant and those with gastro-oesophageal reflux disease. ${ }^{1}$ The marketing gurus offer 'casein-dominant' or 'whey-dominant' proteins, iron fortification or even special supplements such as 'omega-3 acids', 'omega-6 acids', 'probiotics' or 'prebiotics'. How did the human race survive before these designer formulas?

Perhaps the World Health Organization (WHO) should patent breast milk and advocate it as a new formula. Imagine the sales pitch:

\section{NEW MIRACLE FORMULA}

Proven to reduce serious ear, ${ }^{2}$ lung, ${ }^{3}$ urine $^{4}$ and gastrointestinal infections. ${ }^{5}$

Halve the risk of Sudden Infant Death Syndrome. ${ }^{6}$

Protect your child from asthma, ${ }^{7}$ diabetes, ${ }^{8}$ and even obesity. ${ }^{9}$

Exclusive use for more than 4 months adds more than 4 points to your child's IQ. ${ }^{10}$

But wait...there's more: $22 \%$ reduction in breast cancer. ${ }^{11}$

Special unlimited offer: free instant delivery of prewarmed sterilized milk wherever you are, anywhere in the world, any time of the day or night!

Despite these advantages only $35 \%$ of infants worldwide are exclusively breastfed to 4 months, ${ }^{12}$ let alone the current recommendation of 6 months. ${ }^{13}$ This is a dismal result. There are many reasons for this including maternal, ${ }^{14}$ infant and societal factors not all of which are modifiable. Some mothers are aware of the benefits but choose not to breastfeed - as is their right. Our task as an international community is to identify and remove impediments to breastfeeding for mothers considering their options. Recent media cases demonstrate we are failing. A Canadian woman has been threatened with detention under terrorism laws

General Paediatrician and School of Public Health, University of Sydney, Sydney, Australia

E-mail: hgun6897@mail.usyd.edu.au for refusing to stop breastfeeding during a flight, ${ }^{15}$ and an Australian parliamentarian has been ejected from the House for breastfeeding under archaic standing orders prohibiting 'aliens' in the chamber! ${ }^{16}$

It is the choice of every mother and family whether or not to breastfeed their baby. However, to make informed decisions, we need information not misinformation. As direct marketing is restricted, companies sponsor the healthcare industry, provide gifts for new mothers and produce educational posters for early childhood centres and pharmacies. Individuals can assist by notifying the relevant national body when manufacturers breach the WHO code regulating the marketing of breast-milk substitutes. ${ }^{17}$ Health professionals should ensure they provide mothers with up-to-date information on the benefit of breastfeeding. Governments can play their part by expanding the effective UNICEF Baby Friendly Hospital Initiative. ${ }^{12}$

These simple measures are important as breastfeeding could save billions in health care costs, ${ }^{18}$ spare the environment from unnecessary water and agricultural land usage and provide effective family planning acceptable to all religions. However, the most compelling argument for exclusive breastfeeding remains the potential to prevent 1.5 million infant deaths every year in both developed and developing nations. ${ }^{13}$

Conflict of Interest This article was not sponsored by formula manufacturers.

\section{REFERENCES}

1 Breastfeeding Advocacy. List of baby formula manufacturers. At [www.breastfeeding.com/advocacy/advocacy_mfgs.html] accessed 16 October 2005

2 Duncan B, Ey J, Holberg CJ, Wright AL, Martinez FD, Taussig LM. Exclusive breastfeeding for at least 4 months protects against otitis media. Pediatrics 1993;91:867-72

3 Bachrach VR, Scwarz E, Bachrach LR. Breastfeeding and the risk of hospitalization for respiratory disease in infancy: a meta-analysis. Arch Pediatr Adolesc Med 2003;157:237-43

4 Pisacane A, Graziano L, Mazzarella G, Scarpellino B, Zona G. Breastfeeding and urinary tract infection. J Pediatr 1992;120:87-9

5 Bhandari N, Bahl R, Mazumdar S, Martines J, Black RE, Bhan MK. Effect of community-based promotion of exclusive breastfeeding on diarrhoeal illness and growth: a cluster randomized controlled trial. Infant Feeding Study Group. Lancet 2003;361:1418-23

6 McVea KL, Turner PD, Peppler DK. The role of breastfeeding in sudden infant death syndrome. J Hum Lact 2000;16:13-20 
7 van Odijk J, Kull I, Borres MP, et al. Breastfeeding and allergic disease: a multidisciplinary review of the literature (1966-2001) on the mode of early feeding in infancy and its impact on later atopic manifestations. Allergy 2003;58:833-960

8 Kostraba JN, Cruickshanks KJ, Lawler-Heavner J, et al. Early exposure to cow's milk and solid foods in infancy, genetic predisposition, and the risk of IDDM. Diabetes 1993;42:288-95

9 Gillman MW, Rifas-Shiman SL, Camargo Jr CA, et al. Risk of overweight among adolescents who were breastfed as infants. JAMA $2001 ; 285: 2461-7$

10 Mortensen EL, Michaelsen KF, Sanders SA, Reinisch JM. The association between duration of breastfeeding and adult intelligence. JAMA 2002;287:2365-71

11 Newcomb PA, Storer BE, Longnecker MP, et al. Lactation and a reduced risk of premenopausal breast cancer. $N$ Engl $J$ Med 1994;330:81-7
12 World Health Organization. Global Strategy For Infant and Young Child Feeding. Geneva: WHO, 2003

13 United Nations Children's Fund. Breastfeeding: Foundation For A Healthy Future. New York: UNICEF, 1999

14 Barnes J, Stein A, Smith T, Pollock JI, ALSPAC Study Team. Extreme attitudes to body shape, social and psychological factors and a reluctance to breast feed. J Roy Soc Med 1997;90:551-9

15 Fitterman L. Breastfeeding in a time of war. Montreal Gazette 23 April 2003

16 Morton A. Breastfeeding expert decries parliament ban. Age 27 February 2003

17 World Health Organization. The International Code Of Marketing Of Breast-Milk Substitutes: A Common Review And Evaluation Framework. Geneva: WHO, 1996

18 American Academy of Pediatrics. Policy statement: breastfeeding and the use of human milk. Pediatrics 2005;115:496-506 